\title{
TTR
}

Traduction, terminologie, rédaction

\section{Reflections on Translation Studies: Past and Present}

\section{Sherry Simon}

Volume 30, numéro 1-2, 1er semestre-2e semestre 2017

La traductologie en mouvement

Translations Studies: A Forward-Moving Discipline

URI : https://id.erudit.org/iderudit/1060018ar

DOI : https://doi.org/10.7202/1060018ar

Aller au sommaire du numéro

\section{Éditeur(s)}

Association canadienne de traductologie

ISSN

0835-8443 (imprimé)

1708-2188 (numérique)

Découvrir la revue

Citer cet article

Simon, S. (2017). Reflections on Translation Studies: Past and Present. TTR, 30(1-2), 61-78. https://doi.org/10.7202/1060018ar

\section{Résumé de l'article}

Cet article propose une réflexion sur la traductologie et une suggestion de nouvelles pistes de recherche. L'étude de cas est celle des pratiques descriptives instaurées dans les galeries consacrées à l'art canadien et autochtone du Musée des beaux arts du Canada, à Ottawa. Les inscriptions et commentaires qui accompagnent les oeuvres exposées dans ces galeries font une large place aux langues autochtones. Ces nouvelles galeries ouvertes en juin 2017 proposent par leurs traductions une nouvelle identité pour cet art canadien. 


\title{
Reflections on Translation Studies: Past and Present
}

\author{
Sherry Simon \\ Université Concordia
}

\begin{abstract}
This article is a reflection on translation studies and a suggestion for new directions in further research. The case study is that of the new labelling in the National Gallery of Canada which includes labelling in Indigenous languages. In June of 2017, the National Gallery opened newly renovated galleries with a special exhibition of Canadian and Indigenous Art. The translations which are part of this exhibition are important in redefining the identity of Canadian art.
\end{abstract} Keywords: Nida, Summer Institute of Linguistics, TTR, Indigenous languages, National Gallery of Canada

\section{Résumé}

Cet article propose une réflexion sur la traductologie et une suggestion de nouvelles pistes de recherche. Létude de cas est celle des pratiques descriptives instaurées dans les galeries consacrées à l'art canadien et autochtone du Musée des beaux arts du Canada, à Ottawa. Les inscriptions et commentaires qui accompagnent les œuvres exposées dans ces galeries font une large place aux langues autochtones. Ces nouvelles galeries ouvertes en juin 2017 proposent par leurs traductions une nouvelle identité pour cet art canadien.

Mots-clés : Nida, Institut linguistique d'été, TTR, langues autochtones, Musée des beaux-arts du Canada

\section{Language politics}

Let me begin with a story. In 1981, I travelled to Ecuador with my family to spend six months of my husband's sabbatical in Quito. The day we arrived, the president of this stable democracy was killed in a mysterious plane accident. The next day, the government accused the members of an organization called the Summer Institute of Linguistics (SIL) of being CIA spies and expelled 
them from the country. The first event put an end to our hopes for political tranquillity during our stay. The second offered me an enticing subject of research. How could an outfit whose domain was linguistics be considered a threat to this small nation?

I learned that the Summer Institute of Linguistics (Instituto Linguistico de Verano) was the pedagogical arm of Protestant Bible translators. Language training was provided to missionaries before they set out for remote locations in the jungle, where they would translate the Bible from English to the local language and try to convert these isolated groups of Indigenous peoples. Whether they actually worked for the CIA or not, they were considered to wield undue power in areas where the population was especially vulnerable.

Back in Canada, I was able to publish an article on the SIL in a left-wing magazine and shortly after was given a contract to teach translation at Concordia University. How surprised I was to encounter in my university readings the name which had also appeared in my research on the SIL. This was the name of Eugene Nida, premier theoretician of translation during the 1980s and long-time instructor for the SIL. Nida's 1964 book, Towards a Science of Translation, was a staple of translation programs at a time when little other material was available. It offered systematic analysis of questions related to meaning and cultural difference; it also introduced his influential distinction between formal and dynamic equivalence.

But I was perplexed. How could a missionary, a man for whom translation had a very pragmatic and specific goal, formulate principles that would be valid outside of this sphere? My first publication in Translation Studies (Simon, 1987) explored this question, and suggested that Nida's scientific approach was identifiably Christian, taking for granted the idea that the message of any text was to be wrested away from its form. By seeking the spirit rather than the letter, Nida's views clashed with those of two brilliant French thinkers-Antoine Berman and Henri Meschonnic-more closely associated with a Jewish tradition emphasizing the importance of the letter. For instance, the verse from Ecclesiastes familiar to readers of the King James Bible as "vanity of vanities" comes from the Hebrew "havel havalim", meaning "breath of breaths" or "mist of mists". Meschonnic's French translation (1970) stays very close to 
the original idea of mist with "buée des buées". ${ }^{1}$ The Good News Bible, associated with Nida's American Bible Society, goes in the other direction and interprets the phrase to mean: "It is useless". This version can only be valid for an approach to translation which reduces the Bible to an easily assimilated message.

My project allowed me to spend delicious hours in the Birks library at McGill University-one of the most beautiful and wellendowed specialized libraries I have used. Because there were few visitors to the downstairs stacks where the Bible collections were held, those who wished to consult them were given the key to the locked door. The symbolism of this generosity and confidence-the key to this fount of wisdom-was not lost on me. On the other hand, consulting these warring Bibles, with their conflicting interpretations, reinforced the idea that the Bible was used for the promotion of sectarian dogma.

My article "Délivrer la Bible: la théorie d'Eugène Nida" was accepted by Meta (TTR was not born yet). Just before publication I received a message from the editor of the journal, André Clas, informing me of a negative critique by a European Bible scholar. What did I think? I was in Clas' office minutes after receiving his message. He didn't quite understand my alarm, but he was sympathetic to my defense of the article and published it. Though I thought my article might stir up more negative reactions (I thought it was a devastating critique but now realize it was quite tame, and actually quite derivative, in relation to Meschonnic's severe and ongoing condemnation), the article had little response. The value of the article to me, however, was immense. I learned that translations can be partisan. And that theory does not always declare its motivations. Nida was a great scholar and an effective pedagogue. But by declaring "dynamic equivalence" superior to "formal equivalence", by privileging the message over the letter, he was promoting the kind of translation that served his interests and those of his community-translation in the service of conversion. This was by no means an activity devoid of social and political implications. This was clear from the reaction of the Ecuadorian government when it expelled the SIL in 1981.

1. "Buée de buées/buée de buées/a dit le Sage tout est buée/Quel profit pour l'homme/dans tout son effort/l'effort qu'il fera sous le soleil" (Meschonnic, 1970, p. 135). 


\section{The beginnings of TTR}

The lessons of Bible translation were readily transferrable to other contexts. In the Canadian situation, for example, it was easy to see that the Federal model of equal, symmetrical facing-page translations did not carry over to the society as a whole. As a less dominant tongue, French was rarely the source of translations but rather the object. Even in the 1980s, there remained a concern that Quebec culture was in danger of becoming derivative, a language in translation. I began to investigate what had been said about translation in Quebec, from the 1930s onwards. I was able to obtain a small grant from the Office de la langue française, and set out to systematically read everything that had been said by linguists, writers and cultural observers about translation and its effects in Quebec. I discovered ideas that were often negative. Linguists whose mandate was to defend the quality of French in Quebec were wary of the interferences created by translation. When a smaller and marginalized language is faced with a more dominant culture and literature, its response is guarded. While the more powerful language can show a benevolent curiosity, and extol the virtues of translation, the smaller one can legitimately feel fear. Up until this new century, Quebec publishers were not enthusiastic translators. They chose non-fiction mainly, and often works that had something to do with Quebec. It is only since about 2000 that the situation has reversed and Quebec has fully and confidently entered into a culture of translation.

In 1989 Jean-Marc Gouanvic had recently come to Concordia University from the Université du Québec à Trois-Rivières and brought with him a recently founded scholarly journal in the field of Translation Studies. The idea was generous and far-sighted. In 1988, he published my article "Éléments pour une analyse du discours sur la traduction au Québec" in the first issue of TTR. Though in appearance quite different from the work on Bible translation, this analysis was nevertheless informed by the same insights. These are easy to summarize. Far from being a peaceful transaction, carried out across a level playing field, translation carries historical baggage and engages with ideology. It is embroiled in the political and cultural struggles of its time.

However obvious such assertions may now sound, they were new in the context of the embryonic field of translation studies. Neither George Steiner, with his magnificent After Babel (1975) 
or Jean-Paul Vinay and Jean Darbelnet with their enlightening Stylistique comparée du français et de l'anglais (1958) or even Susan Bassnett's extremely useful Translation Studies (1980) proposed any real kind of political analysis. This would only really emerge with postcolonial theory. It was Tejaswini Niranjana's Siting Translation in 1992 that launched postcolonial critique, a fruitful area of study stimulating many insightful works on the implication of translation in the uneven traffic initiated through colonialism. This work was especially abundant and meaningful in India, with stunning contributions by such scholars as Harish Trivedi, Meenakshi and Sujit Mukherjee, Vanamala Viswanatha, Paul StPierre, Rita Kothari, AK Ramanujan, Gayatri Spivak and othersalthough in the Canadian context an awareness of the political dimensions of translation were inescapable, and already discussed, most influentially by Annie Brisset in Sociocritique de la traduction (1990). No longer could translations be viewed as abstract linguistic entities subject to pure descriptive analysis: they became worldly texts imbued with social, political and economic power relations and acting within a broader cultural scene. Far from being simply a matter of contrastive linguistics, translation was now regarded as a complex intercultural process for which the contexts of communication became of foremost importance.

The importance given to space-the geographical contexts of translation (India to Britain, Calcutta to London) but also the context of theory itself-had far-ranging epistemological and methodological consequences. To see translation theory as situated in space introduces relativity into the very nature of theorizing. To explore spatial frameworks, as Kobus Marais asserts, necessarily implies that "one steps out of the Enlightenment idea of universal knowledge", and "gives up knowledge for knowledges" (2013, p. 4). Geography influences the ideas and values that are brought to translation studies. Attention was drawn to the different preoccupations of academic work issuing from "smaller nations" or "nations obliged to translate" in contrast with academic work from the imperial centres of the US, Britain or France. That translation theory was a special concern for politically marginal countries like the Netherlands, Israel or Canada acknowledged the reality of geopolitical spaces carrying the burden of translation (ibid., p. 5). It was acknowledged that many parts of the globe were neglected in the study of translation flows, with little information on the history 
of major translating traditions outside Europe and North America, or indeed the very conceptualisation of translation outside the Greco-Latin tradition. More recently has come a realisation of the very partial understanding of the spaces that translations occupy outside of the formal economy and the structures of understanding fostered by the discipline. And so translation spaces have come to stand for the need to explore translation activity that stands outside the traditional purview of academia: the translation of the informal economy (ibid., p. 194) and of the various forms of non-professional translation (Pérez-González and Susam-Saraeva, 2012) including political dissent (Baker, 2015).

Where Canadian work most effectively contributed to this international awareness of power differentials was in the area of gender. The contributions of Barbara Godard, Kathy Mezei, Susanne de Lotbinière-Harwood, Luise von Flotow and others were truly pioneering. Their writing underlined the productive nature of translation as dialogue. Feminist translation came with its own agenda, but - in contrast with $\mathrm{Nida}$, for example - this agenda was entirely above board. L'écriture au féminin had as its goal to reorder the structures of patriarchal language. Translators of French feminism appropriated this program, using various kinds of strategies to enact parallel changes. The 1980s and 1990s saw a heady period of cultural creation, in which translation had a strong role to play.

\section{Expanding the field}

This sense of enthusiasm and creativity was evident in the work of $T T R$. During the first years, when I had the privilege of being part of the editorial board, there was a sense of excitement with each new issue. Some of our friends who were so important during those years are no longer with us and are much missed: Barbara Godard, Daniel Simeoni, Antoine Berman. All three were brilliant theorists and their contributions were absolutely foundational.

$T T R$ has played an important role in promoting and strengthening Translation Studies in Canada. The first issues show a remarkable coherence of focus, with a strong emphasis on the conjunction of translation and culture. Over the years, the journal has been crucial in supporting a recognizable body of Canadian translation theory as well as the expanding reach of translation studies as it opens into ever wider areas of investigation. In the recent explosion of research 
focused on socially situated practices of translation, scholars have been actively seeking out practices of translation situated outside the traditional purview of analysis: the informal economy (Marais, 2013), publishing houses (Buzelin, 2006), military institutions (Baigorri-Jalon, 2011; Heimburger, 2012), Nazi concentration camps (Wolf, 2016), the conference rooms of Cold War diplomacy (Fernández-Ocampo and Wolf, 2014), refugee camps (MoserMercer, 2013-2016), political spaces of dissent (Baker, 2015) and cities (Simon, 2006, 2012; Cronin and Simon, 2014). Interest in the translation of justice has turned attention to the Nuremberg trials, the founding of the United Nations and the trials of the International War Tribunal as well as refugee hearings today (Elias-Bursac, 2015; Inghilleri, 2012). It is not incidental that many of these studies deal with zones of conflict and violence. It is in this context that it is relevant to speak of spaces of forced translation-where policing or surveillance results in constraints funnelling language traffic in one direction only. The notion of the "translation zone", adapted from Mary Louise Pratt's "contact zone", and explored by Emily Apter (2006), has been explicitly and implicitly adopted by a number of theorists (Cronin, Simon, Baer, Wolf) concerned with exploring socially situated translation practices which are not anchored within or delimited by national contexts.

The broad category of translation zones calls up border cultures of all kinds-those created across the contact zones of city neighbourhoods, or at the nodal points where virtual and material realities intersect. The varying spatial dispositions of cities and their diverse language histories have given rise to a growing literature on their distinct translational histories, for instance, the multilayered overwriting of Central European cities like Lviv, Vilnius, or Czernowitz, the mythical language past of New Orleans; the continuing conflicts of language in Istanbul; the work of mediation in Antwerp (Cronin and Simon, 2014; Simon, ed., forthcoming).

There are those who worry about the expanding borders of Translation Studies. I do not share those fears, though I understand that such expansion might carry the risk of weakened disciplinary rigour. But research which simply defends and illustrates proven paradigms does not always come up with the most illuminating results. Rigour and experimentation must be balanced. Translation Studies has experienced over the last thirty years a surge of extraordinary growth and spectacular insights. The results of the move- 
ment inaugurated by TTR in 1988 have been convincing. Our understanding of Canada and of the world has been vastly enriched.

\section{Translation effects: A trip to the museum}

In this section I present a case study relating to some of the issues I introduced above. Much new work in Translation Studies focuses on what can be called translation "effects" and this is the title that Kathy Mezei, Luise von Flotow, and I gave to our edited volume on translation in Canada (2014) A new form of translation history and a companion to Translation Studies in Canada, the book moves beyond restrictive notions of official translation in Canada, analyzing its activities and effects on the streets, in movie theatres, on stages, in hospitals, in courtrooms, in literature, in politics, and across café tables. Translation Effects presents 32 detailed case studies of specific events and examines the reverberation and spread of their effects. Through these imaginative, at times unusual, investigations, the contributors reveal the omnipresence of translation in Canadian life.

The effects of translation can be particularly vivid when they concern fragile or marginalized languages. This is the case for Indigenous languages in Canada, and the volume features six separate articles on Indigenous languages, illustrating the very diverse effects which the interaction between colonial and Indigenous languages can generate-in the courtroom, on the stage or on the screen. One of the most compelling examples of translation effects is the 1998 movie Big Bear, directed by Gil Cardinal and written by Rudy Wiebe- and described in the volume by Ray Ellenwood. The movie tells the story of the ill-fated 1885 rebellion in the Canadian northwest. What is most important to the experience of the film is the unusual sound track. The Aboriginal characters speak in idiomatic English, while the white soldiers of the North-West Mounted Police utter an incomprehensible babble. This means that the viewer sees and hears the tragic events of 1885 from the perspective of the Aboriginal populations because they speak a familiar language (idiomatic English) while the soldiers are depicted as foreign and incomprehensible. The viewer is forced to enter into the subjective position of Big Bear's followers, forced to understand the repressive power of language. No subtitles accompany the barkings and babblings of the soldiers, and so the viewer can only guess at the meaning of what is being said. This reversal brings the burden of translation into sharp focus. Who is obliged to translate and who 
will suffer the consequences of the inevitable miscommunication that will result?

Reversals of a different order are being experimented with in many different areas of Canadian culture today-with a revival of Indigenous languages and their use in numerous creative projects. Museums have seen changes in the public presence of Indigenous languages, and it is one example of such a change that I would like to highlight here as the second part of this reflection: Translation studies in the present.

In June of 2017, the National Gallery opened newly renovated galleries with a special exhibition of Canadian and Indigenous Art. As part of the celebrations of Canada's 150 years, the event had unusual symbolic importance. The exhibition and its setting were to be the latest word on what "Canadian art" is and means.

The novelty of the displays is easy to summarize. Works of Indigenous art are interspersed with other kinds of Canadian art to create a new narrative about what precisely constitutes the body of work called Canadian art. The displays are largely arranged chronologically, beginning with ancient Indigenous objects and examples of the religious art of New France, and ending with modern Inuit sculptures and geometric abstract paintings. The new spacious rooms include some eight hundred works of art from the National Gallery's own collections of Canadian and Indigenous art, and photographs, and are supplemented by loans of Indigenous sculptures and objects by Inuit, Métis, and First Nation artists. The presence of these loaned works is crucial, because at the time that the Museum developed its collection these would not have been considered art but rather ethnographic artefacts-and left to ethnographic museums to collect and display. "The newly transformed galleries provide the ideal setting to tell a more complete story of art making in this land, which dates back thousands of years," said National Gallery of Canada Director, Marc Mayer (National Gallery, 2017, n.p.). This, he says, is a "meaningful display, representative of Canada's unique diversity and heritage" (ibid.).

\section{The Second Museum Age}

Though the changes are easy to summarize, they represent the outcome of decades of debate about the nature of museums and their public mandate. The transformation was precipitated by the conclusions of the Truth and Reconciliation Commission of Canada 
(2015) encouraging museums to be more attentive to Indigenous culture. The exhibits display the characteristics of what art critic and curator Ruth Phillips (2011) calls the Second Museum Age, in which new museological practices are designed to make museums more inclusive by highlighting cross-borrowings between the ethnological and the fine arts traditions, and by encouraging a culture of shared power and authority incorporating the values and perspectives of Aboriginal people in Canada. This culture of shared power is enacted in all aspects of museum life, including curating, research, and policy. The museum is reconfigured as an experimental laboratory, embracing a plurality of knowledges, and out of which can come models of respectful dialogue (Phillips, 2011).

Translation is an important part of these practices, though it is rarely highlighted as such. The most exciting developments in language policies have been related to the expanded role of Indigenous languages. Because they have increasingly sought to include the voices of artists responsible for the making of Indigenous art, museums have been looking for innovative means of including these voices (see Everett-Green, 2017). This is done for instance for the oral presentations of stories and songs of Indigenous communities that are included in some museums. The Vancouver Museum of Anthropology has been pioneering in these practices, making the portraits and voices of contemporary makers of Indigenous art very present in their displays. Translation is provided in the form of voice overs or English versions. In the Museum of History (formerly the Museum of Civilization) in Ottawa, a new display was created in the Canadian History Hall opening in the spring of 2017 highlighting the role of First Nations in the history of Canada. The introductory panel is a large illuminated animation telling the creation story of the Anishinaabe people, the people "upon whose traditional territory the museum sits" (McCue, 2017, n.p.). Visitors are greeted by this striking panel, in which the story is recounted orally entirely in the Anishinaabemowin language. Subtitles are provided at the bottom of the screen in French and English. As an introduction to the story of Canada in which the First Nations are now given a foundational role, the attractive starry display with its accompanying narrative, is extremely effective. However, that is the only instance in the entire exhibition spanning some five centuries in which First Nations languages are prominent. (To be fair: The Museum has a First Peoples Hall which is exclusively devoted to 
aboriginal peoples, and so I am not suggesting that the history is neglected but rather the languages.)

\section{Writing Indigenous languages}

Across the river from the National Museum of History, the new exhibitions of the National Gallery have included Indigenous languages in a different way-focusing on written language. And the impact of this novelty is enhanced by the symbolic prestige of this national institution. The innovation has to do with the labelling of Indigenous items in the collection. While government policy imposes the necessity of providing bilingual labels-English and French-throughout the museum, a number of Indigenous items in the collection were given labels in Indigenous languages. Rather than imposing one standard Indigenous language on all the items, the labels were made in seventeen different languages, each item being accompanied by a label in the language of the community from which it originated.

The public information provided on the process of translation is limited to a few sentences on the website.

As part of the planning process for the new Canadian and Indigenous Galleries, the Gallery established two Indigenous Advisory Committees of curators, academics, knowledge-keepers and other recognized authorities to provide expertise and guidance on interpretation, display protocols and community engagement. Gallery staff also reached out to authors and translators to produce more than 50 gallery texts in 17 Indigenous languages from across the country and consulted with local Algonquin Elders on how to officially welcome the various objects from Indigenous communities. These objects include the ancient rock art called the Beaver Hill Petroglyph from Saskatchewan, and the ceremonial Raven Rattle from Haida Gwaii, British Columbia. Consultation with the members of the Indigenous Advisory Committees will continue after the opening of the Canadian and Indigenous galleries, along with other education and engagement initiatives. (National Gallery of Canada, 2017, n.p.)

The result is a practice of labelling which has unusual visual impact. Languages which do not normally appear in the context of a museum display are given a presence that is identical to that of official languages, English and French. While Indigenous languages may have been present in museums before, their role was as an object of knowledge; here they figure as subjects-as interpretive voices. 
The presence of these languages also has an interpellative effect. They salute those readers of the language who find themselves in the space of the museum. They create a widened community of participants, "changing the distribution of voices in the translation practice" (Sturge, 2007, pp.168-169). The translation is in fact an invitation, or a summons, requiring the presence in these museum spaces of individuals able to read and appreciate these messages in their own tongue. At the same time, these labels bring into existence a form of expression (the description of art works) that may not have existed as such in the written form of the language, because Indigenous languages have been transmitted principally in oral form-the written forms being mainly used in educational settings, in programs of language revival for instance. Rather than finding an equivalent for a reality "already there", the written form of the language solicits something new, a not already existing form of expression communicating the knowledge and role of the artwork within the community.

This redistribution involves a giving up of physical space to the presence of different languages, as well as a change in the relative weight of authority granted to original and translation.

In terms of an ethics of translation this implies a demand on the majority target language to cede some of its power to the originating language, holding back and allowing the source language more space to speak. (Sturge, 2007, pp. 168-169)

In a discussion of an exhibit at the Horniman museum in London in the late 1990s, Kate Sturge draws attention to the immense symbolic importance of the presence of African languages such as Yorubaas a means of saluting the immigrant populations of London but also as "an intervention into the city's political and social texture via translation - translation in a panoramic and politicized version, which is driven on by the presence of a vocal and active diasporic community in the city" (ibid., p. 173).

\section{Translating from or to?}

The presence of the three languages side by side gives no clue as to the actual direction of translation. Which is the original, which is the translation? The symmetrical blocks of English and French text which are a feature of official government communication in Canada perpetuate a fiction of equivalence which includes the 
status of the languages themselves. But in fact, English is by far the more powerful language in the country and the one from which the vast majority of messages are translated. In the case of the labelling in Indigenous languages, there is no indication as to whether there was a process of transfer from or to.

I was able to obtain the following information. ${ }^{2}$ Of the roughly 200 Indigenous works displayed, 150 were selected for extended labelling by a person from the Indigenous community. In accordance with the highlighting of the creators of Indigenous art, this labelling would give more context to the piece, describe the making of it, its role in the community, and any other relevant information. When the consultation first began, the members of the education department responsible for this process expected the translation process to be from the Indigenous language to French and English, that is, that the knowledge about the art work would be provided by the person who was part of that community in their own language. In the end, as in almost every case the speakers did not have the vocabulary in their own languages to provide this information, as these experts would have been trained in English or French, the translation happened in the other direction.

The ambiguity about the directionality of translation reflects the situation of Indigenous languages within the context of First Nations political and cultural struggles today. Because of the generations of those forced to attend Residential Schools, many First Nations in Canada were forcibly cut off from their languages, prohibited from speaking them and inculculated with a disdain for them. Some spoken languages were maintained, but written forms were much more unusual - and today slowly reappearing in the context of language revival programs. And so translation into an Indigenous language could sometimes entail the invention of forms of expression perhaps never used before.

This process can be compared in some ways to activist translation or to the kind of "as if equivalence" through which marginalized groups for instance reanimate a neglected past, valorize marginalized languages or text-types, or produce innovative forms of writing or vocabulary into language systems. Unlike translations that have a purely informative function, activist translations have a

2. In an email exchange with David Gillanders, Education Department, National Gallery of Canada. 
more proactive intention where-if the equivalent form does not yet exist-it is created through neologisms or through unusual uses of syntax or rhetorical effects.

Of the labels prepared by June 2017, the languages were: Anishinabemowin, Inuktitut (6 different dialects), Haida Masset, Blackfoot, Michif, Kanyen'keha (Mohawk), Ojibwe, Gwich'in, Kwakwala, Western Abenaki, Naskapi. What is striking is in fact the very diversity of the commentaries themselves. Some are more technical, simply describing the accompanying items, some are narratives, some are interventions such as the comment accompanying a War Scenes painted by the artist known as Blackfoot White Wolf: "Today's generation fights a different battle but still advocates for the protection of land and water."

The relation between language and art takes on a fascinating light in the commentary accompanying the drawing by Helen Kalvak. The label reads:

I was then taking practical lessons in the Eskimo language from a superb grandmother, Helen Kalvak, collecting stories of the past. Sometimes to explain, she would make a drawing. One day I asked her to make me an Eskimo parka out of caribou hide and, contrary to Eskimo fashion, she drew a design of it. She was on her way to becoming a remarkable artist, with many designs to her credit.

Father Henri Tardy is the author of this commentary, which presumably was first written in French. Teaching the Inuit language is the reason that Helen Kalvak was encouraged to draw, and the priest's request for a parka elicits this particular rendition. It is particularly fitting then that this lovely story appear in Inuktitut and that the drawing be accompanied by the language which was in many ways its origin. A Roman Catholic priest who spent forty years in the North and who subsequently became an adept of meditative and contemplative traditions, Tardy is credited with establishing the first Inuit printmaking and lithographic cooperative in the North in 1965, which today remains a source of creativity and income for the community of Holman. The translation of Tardy is not in syllabics, but in Latin letters.

Particularly noteworthy is the text in Michif which accompanies the acrylic entitled Sainte-Madeleine (2006) by David Garneau, Métis. The question of whether Michif (a mixture of French and Cree) actually qualifies as a "language" is here given an emphatic 
answer. Though legitimized by linguists (Bakker, 1997) and Métis organizations, the mixed contact language struggles for recognition. Its presence here signals its condition as a language like the others, though the commentary evokes the tragic events in which the Métis population was involved. Forced to flee from the Red River after the events of 1869-1870 and to settle at Ste. Madeleine, they were displaced again in 1941 because they were considered squatters.

A more traditionally descriptive label accompanies the work of critically acclaimed abstract artist, Rita Letendre. The label for her oil on canvas from 1963 explains:

Letendre's unique artistic vision draws on her interest in Zen teachings, her French and Abenaki heritage, and an intuitive exploration of the gestural application of paint. This turbulent mix of red and black evokes a wound, creating tension and suggesting brooding violence. Although she later explored hard-edge abstraction, the themes of light and energy have remained constant in her work.

This text is rendered in French and Abenaki and possibly suggests a translation from French.

\section{Reversals}

The National Gallery labels confirms the opening of a new chapter in the history of translation of Indigenous languages in Canada. While literary and ethnological translations of First Nations stories were translations out of Indigenous languages, (Cardinal 2014), new reversals see increasing translation into these tongues. The labels of the National Gallery, the restoration of Ashinaabe street names in Toronto, increasing numbers of art exhibitions and films which give solid representation to First Nations languages, the introduction of new legislation for Indigenous languages in Canada (in 2019): these are acts of translation which have the force of redress.

\section{References}

Apter, Emily (2006). The Translation Zone. Princeton, Princeton University Press.

Baer, Brian James, ed. (2011). Literary Translation in Eastern Europe and Russia. Amsterdam/Philadelphia, John Benjamins.

Baigorri-Jalon, Jesus (2011). "Wars, Languages and the Role(s) of Interpreters." In H. Awaiss and J. Hardane, eds. Les liaisons dangereuses: langues, traduction, interprétation. Beyrouth, École de traducteurs et d'interprètes de Beyrouth, pp. 173-204. 
Baker, Mona, ed. (2015). Translating Dissent: Voices From and With the Egyptian Revolution. London and New York, Routledge.

Bakker, Peter (1997). A Language of Our Own: The Genesis of Michif, the Mixed Cree-French Language of the Canadian Metis. Oxford, Oxford University Press.

Bassnett, Susan (1980). Translation Studies. London, Methuen.

Brisset, Annie (1990). Sociocritique de la traduction: théâtre et altérité au Québec (1968-1988). Longueuil, Le Préambule.

Buzelin, Hélène (2006). "Independent Publisher in the Networks of Translation.” TTR, 19, 1, pp. 135-173.

Cardinal, Philippe (2014). "1999: Cross-Purposes: Translating and Publishing Traditional First Nations Narratives in Canada at the Turn of the Millennium." In L. von Flotow, K. Mezei and S. Simon, eds. Translation Effects. The Shaping of Modern Canadian Culture. Montreal and Kingston, McGill-Queen's University Press, pp. 271-289.

Cronin, Michael and Sherry Simon, eds. (2014). "The City as Translation Zone." Special issue of Translation Studies, 7, 2.

Elias-Bursac, Ellen (2015). Translating Evidence and Interpreting Testimony at a War Crimes Tribunal Working in a Tug-of-War. London, Palgrave.

Ellenwood, Ray (2014). “1885, 1998: Translating Big Bear in Film.” In L. von Flotow, K. Mezei and S. Simon, eds. Translation Effects. The Shaping of Modern Canadian Culture. Montreal and Kingston, McGillQueen's University Press, pp. 27-36.

Everett-Green, Robert (2017). "On Show this Summer: An Inclusive New Approach to Indigenous Art." The Globe and Mail, June 20. Available at <https://www.theglobeandmail.com/arts/art-and-architecture/onshow-this-summer-an-inclusive-new-approach-to-indigenousart/ article35406138/> [consulted August 15, 2018].

Fernández-Ocampo, Anxo and Michaela Wolf, eds. (2014). Framing the Interpreter: Towards a Visual Perspective. London and New York, Routledge.

Flotow, Luise von, Kathy Mezei and Sherry Simon, eds. (2014). Translation Effects. The Shaping of Modern Canadian Culture. Montreal and Kingston, McGill-Queen's University Press.

Heimburger, Franziska (2012). "Of Go-Betweens and Gatekeepers: Considering Disciplinary Biases in Interpreting History through Exemplary Metaphors. Military Interpreters in the Allied Coalition during the First World War." In B. Fischer and M. Nisbeth Jensen, eds. Translation and the Reconfiguration of Power Relations. Revisiting Role and Context of Translation and Interpreting. Graz, Lit-Verlag, pp. 21-34. Inghilleri, Moira (2012). Interpreting Justice: Ethics, Politics and Language. London and New York, Routledge. 
Marais, Kobus (2013). Translation Theory and Development Studies: A Complexity Theory. London and New York, Routledge.

McCue, Duncan (2017). "Canada's Biggest Museum Teams with Indigenous Graphic Artist to Animate Creation Story." CBC Radio. June 26. Available at <http://www.cbc.ca/radio/checkup/blog/canadas-biggest-museum-teams-with-indigenous-graphic-artist-to-animatecreation-story-1.4178060> [consulted August 15, 2018].

Meschonnic, Henri (1970). Les Cinq rouleaux. Paris, Gallimard.

Moser-Mercer, Barbara (2013-2016). "InZone." Global Studies Institute, Université de Genève. Available at <http://inzone.unige.ch/index.php? module $=$ content\&type $=$ user\&func $=$ view\&pid $=25>$ [consulted August 2, 2018].

National Gallery of Canada (2017). "The New Canadian and Indigenous Galleries Open June $15^{\text {th }}$ at the National Gallery of Canada." Press Release, June 7. Available at <https://www.gallery.ca/for-professionals/ media/press-releases/the-new-canadian-and-indigenous-galleriesopen-june-15th-at> [consulted August 15, 2018].

Nida, Eugene (1964). Towards a Science of Translation. Leiden, E. J. Brill.

Niranjana, Tejaswini (1992). Siting Translation. History, Post-Structuralism, and the Colonial Context. Berkeley, University of California Press.

Pérez-González, Luis and Şebnem Susam-Saraeva (2012). "Nonprofessionals Translating and Interpreting. Participatory and Engaged Perspectives." The Translator, 18, 2, pp. 149-165.

Phillips, Ruth B. (2011). Museum Pieces. Toward the Indigenization of Canadian Museums. Montreal and Kingston, McGill-Queen's University Press.

Pratt, Mary Louise (1992). Imperial Eyes: Travel Writing and Transculturation. London and New York, Routledge.

Pratt, Mary Louise (2016). "Lessons for Losing." CR: The Nerw Centennial Review, 16, 1, pp. 245-251.

Simon, Sherry (1987). "Délivrer la Bible : la théorie d'Eugène Nida." Meta, 32, 4, pp. 429-437.

Simon, Sherry (1988). "Éléments pour une analyse du discours sur la traduction au Québec.” TTR, 1, 1, pp. 63-81.

Simon, Sherry (2006). Translating Montreal: Episodes in the Life of the Divided City. Montreal and Kingston, McGill-Queen's University Press.

Simon, Sherry (2012). Cities in Translation. Intersections of Language and Memory. London and New York, Routledge.

Simon, Sherry, ed. (2016). Speaking Memory. How Translation Shapes City Life. Montreal and Kingston, McGill-Queen's University Press.

Simon, Sherry, ed. (forthcoming). Translation. An Interdisciplinary Journal. Forthcoming issue on Translation and Space. 
Steiner, George (1975). After Babel. Aspects of Language and Translation. Oxford, Oxford University Press.

Sturge, Kate (2007). Representing Others: Translation, Ethnography and the Museum. London and New York, Routledge.

Truth and Reconciliation Commission of Canada (2015). "Truth and Reconciliation Commission of Canada: Calls to Action." Available at $<$ http://www.trc.ca/websites/trcinstitution/File/2015/Findings/Calls_ to_Action_English2.pdf> [consulted August 2, 2018].

Vinay, Jean-Paul and Jean Darbelnet (1958). Stylistique comparée du français et de l'anglais : méthode de traduction. Montreal, Beauchemin.

Wolf, Michaela (2015). The Habsburg Monarchy's Many-Languaged Soul: Translating and Interpreting, 1848-1918. Trans. Kate Sturge. Amsterdam/Philadelphia, John Benjamins.

Wolf, Michaela, ed. (2016). Interpreting in Nazi Concentration Camps. London, Bloomsbury Academic.

Sherry Simon

Département d'études françaises

Concordia University Montreal (Quebec), Canada sherry.simon@concordia.ca 